\title{
SUMMA THEOLOGIAE 2.0: INTELLECTUAL MASS MEDIA IN THE MODERN RUSSIAN REALITIES, OR HOW “THE ACADEMIC" BECAME "THE MEDIATIC”
}

\author{
Maksym W. Kyrchanoff \\ Voronezh State University. Voronezh, Russia. Email: maksymkyrchanoff[at]gmail.com
}

\begin{abstract}
The research paper focuses on the specific features of the status of theology in the modern humanities in Russia. Studying the complexities and difficulties of the institutionalisation of theology and its localisation in the Russian university system and academic culture, the author foregrounds the post-Soviet European experience of the Baltic countries and Ukraine, where theology acquired the status of a "normal" science earlier than in Russia. Within the framework of this study, the peculiarities of the controversial status of theology in the system of higher education as well as in the Russian postgraduate and doctoral studies are considered in the contexts of the frontier of knowledge and the post-Soviet stereotypes. It is assumed that several factors, including the Soviet atheistic cultural heritage, the post-Soviet system of secular degrees and the traditionally significant role of representatives of the natural sciences in the academic community, may significantly contribute to slowing down the transformation of theology into a "normal" science. The paper also deals with the issue of how theology is transforming from the church life of the Russian Christians and becoming more noticeable in the Russian educational cultures and academic spaces. The arguments of the supporters and opponents of the official institutionalisation of theology in the higher education system are critically examined. The author pays special attention to the prospects and possibilities of using the Western experience of "secularization" of theology and its integration into the secular canons of science.
\end{abstract}

\section{Keywords}

theology; science; mass media; intellectual communities; dissertations; "holy war"; Church; secularization; clericalisation; academic communities; academic ethics

This work is licensed under a Creative Commons «Attribution» 4.0 International License 


\title{
SUMMA THEOLOGIAE 2.0: \\ ИНТЕЛЛЕКТУАЛЬНЫЕ МАССМЕДИА В РОССИЙСКИХ РЕАЛИЯХ, ИЛИ КАК «АКАДЕМИЧЕСКОЕ» СТАЛО «МЕДИЙНЫМ»
}

\author{
Кирчанов Максим Валерьевич \\ Воронежский государственный университет. Воронеж, Россия. \\ Email: maksymkyrchanoff[at]gmail.com
}

\section{Аннотация}

В статье анализируются особенности статуса теологии в современных гуманитарных науках в России. Изучая сложности и трудности институционализации теологии и ее локализации в российской университетской системе и культуре, автор статьи актуализирует постсоветский европейский опыт стран Балтии и Украины, где теологии обрела статус «нормальной» науки раньше, чем в России. В рамках данного исследования рассматривается спорный статус теологии в системе высшего образования, а также в российской аспирантуре и докторантуре в контекстах фронтирности знания и постсоветских стереотипов. Предполагается, что несколько факторов, включая советское атеистическое культурное наследие, постсоветскую систему светских степеней, традиционно значительную роль представителей естественных наук в академическом сообществе существенно замедляют процессы превращения теологии в «нормальную» науку. В статье представлен анализ того, как теология мигрирует из церковной жизни российских христиан, становится видимой и проявляется в российских образовательных и академических пространствах, а также приводятся аргументы и доводы как сторонников, так и противников официального институционализации теологии в системе высшего образования. Особое внимание уделяется перспективам и возможностям использования западного опыта «секуляризации» теологии и ее интеграции в светские каноны науки.

\section{Ключевые слова}

теология; наука; интеллектуальные сообщества; масс медиа; диссертации; система ученых степеней; “холивар”; Церковь; секуляризация; клерикализация; академические сообщества; академическая этика

Это произведение доступно по лицензии Creative Commons «Attribution» («Атрибуция») 4.0 Bceмирная 


\section{THE PURPOSE AND OBJECTIVES OF THE ARTICLE}

Modern Russian media are extremely heterogeneous, and their information agenda is extremely diverse. Intellectual mass media have a special and unique status, and their subject matter corresponds to their specifics. Theology and the problems of its scientific character or unscientific nature became the subject of the Russian intellectual media attention after 2017, when Pavel Khondzinsky defended his first dissertation in theology, receiving a "Candidate of Science" degree. In the last decades this defence and the return of theology to the mainstream science ignited a "holy war" among Russian intellectuals, who were extremely active in their attempts to challenge the status of theology or to prove its right to be a normal science. Moreover, these discussions forced the intellectual media to turn theology into an information occasion and transformed it into the media topic that occupied its place in the Russian information spaces and produced a variety of assessments and perceptions of theology, which vary from timid attempts to rehabilitate it to radical rejections. Formally, the academic issues became an information occasion with the aim of integrating theology in mass media discourse. The "misadventures" of theology in the Russian cultural and intellectual mass media actualised its controversial status and inspired intellectuals to form new agenda, splitting or consolidating society.

Therefore, the research aim is the analysis of the trajectories of perception of theology as an information occasion that turned intellectuals into the combatants of the culture wars in the modern Russian mass media. To accomplish the research aim, several objectives are to be achieved, including the analysis of the external stimuli and factors that turned theology into an information occasion, the reason for the consolidation and fragmentation of intellectual communities, as well as the main viewpoints and arguments expressed by them in the modern theological "holy wars".

The research aim and objectives determine the corpus of the sources represented mainly by polemical texts and intellectual journalism. However, it is worth noting that the author does not base the analysis on the scientific texts about the place, role and status of theology in the contexts of the humanities (Bokov, 2013; Gaginsky, 2019; Malimonova, 2015; Snisarenko, 2020; Shmonin, 2019), presuming that they can become the basis for other studies with different goals and objectives. 


\section{THEOLOGY: SCIENCE, NON-SCIENCE, OR INFORMATION REASON, OR HOW THE EXTERNAL POLITICAL FACTORS TURNED THEOLOGY INTO AN INFORMATION PREDICTION}

Institutional background or the factors that facilitated the transfer of theology from the academic field into mass media discourse. Modern Russian science continues to use the principles of organisation and institutionalisation inherited from the Soviet state system. Therefore, Russian science institutionalized in the form of institutes in the structure of the Academy of Sciences or universities is predominantly secular and statesponsored. Comparing the Soviet system of science in the context of the hierarchy and classification of humanitarian knowledge, it is evident that the post-Soviet Russian science changed insignificantly. New specialities did not appear in the passports of "scientific specialities", whereas political science became the only Russian post-Soviet exception of "new" science. Regional studies have not received official recognition as a scientific speciality so far, although Regional Studies are actively developing in the higher education system.

There are virtually no radical transformations in the system of candidate and doctoral degrees as well as essential changes in the defence of dissertations in the Russian post-Soviet academic culture. In fact, the bachelor and master's degrees are predominantly educational qualifications, and there is a gap between them and the candidate and doctoral degrees. The transformation trajectories of Russian higher education and science in this situation are developing discretely. While some sciences in Russia have a formally correct reputation, others have become information occasions and stimuli for discussions that are far from science and the norms of academic ethics, being an element of ideological debates.

The difficulties and contradictions in the development of theology in modern Russia generate the problems and contradictions of higher education and the degree system on the whole. Therefore, the problematic status of theology as a frontier form of knowledge in the contemporary situation highlights the contradictions of the Humanities and the defence of dissertations in modern Russia. Theology is a frontier because theology is both part of the Church culture and humanities. Furthermore, it stimulates the fragmentation of the Russian academic community and promotes disputes between the supporters of the secular model of the development of science and those intellectuals who believe that the situation of coexistence of secular and non-secular forms of knowledge is normal. Thus, the above-mentioned problems are in the focus of the author's attention. 


\section{From "scientific atheism" to religiovedenie: the post-soviet inertia or the humanities without theology.}

The Soviet model of science developed as a dichotomy being controlled and directed by the communist regime, which divided science into the formally correct and ideologically incorrect and dangerous. If the natural sciences and the humanities, after the radical experiments of the 1920s, by the early 1930s, restored their scientific status, theology became an exception from the Soviet logic of science development. The Soviet government declared the separation of Church from the state formally but used the tactics of persecution and repression for control of religious groups and communities. Religious education in the Soviet educational system was separated radically from the secular and considered to be something archaic.

Despite the policy of state atheism, the Soviet regime recognised the right of the Orthodox and Catholic churches to have their educational institutions, but they remained under the political and ideological control of the authorities. As for the degree system, the Church awarded the degrees of the Candidate of Theology (kandidat bogosloviia) and the Doctor of Theology (doktor bogosloviia), but in fact, the atheist state which controlled church life sanctioned the possibility of defence of dissertations in theology. The Moscow Theological Academy and the Leningrad Theological Academy, as two leading Orthodox educational institutions in the USSR, received the right in 1946 to confer the degrees of the Candidate and Doctor of Theology, but these degrees had an intra-church status and recognition because the Soviet state did not include these academic degrees into the state system.

The Soviet state did not extend financial surcharges to the Candidates and Doctors of Theology, which could be received by scientists who received any secular degree. Therefore, in the informal hierarchy, the Candidate of Theology in the Soviet "table of ranks" had a less prestigious status than, for example, the Candidate of Historical or Philosophical Sciences. This situation of inequality stimulated some priests to obtain secular degrees, although some of them became candidates of science before becoming priests. Some priests such as Archbishop Luka or Valentin Felixovich Voyno-Yasenetsky (1877 - 1961) who was both a Doctor of Medical Science and a Doctor of Theology and even a winner of the Stalin Prize of the first degree) were famous scientists during the Soviet period but such situations were unique and exceptional.

The collapse of the Soviet Union did not stimulate the automatic equalisation of secular and ecclesiastical academic degrees, visualising the frontier status of the Candidates and Doctors of Theology. The end of the policy of forced atheisation stimulated trends of clericalisation of the post-Soviet society, but theology in the 1990s did not become a recognised academic 
discipline because the post-Soviet universities chose imaginary religious studies or religiovedenie as a compromise between the Soviet scientific atheism and Western theology. Russian religious studies retained continuity with the Soviet scientific atheism. Thus, the intellectuals who defended their dissertations during the Soviet period, became automatically specialists in the problems of history, philosophy and sociology of religion in the 1990s.

If before 1991 the Soviet intellectuals wrote about the crisis of religion and its decline in a capitalist society, then in the 1990s the same authors, with the enthusiasm of neophytes, began to popularise the ideas they had criticised several years earlier. The churches in the post-Soviet situation continued to award their Candidate and Doctoral degrees when the secular state integrated the religious topics in dissertations into the historical, philological, philosophical, political, and sociological sciences. Therefore, there was no place for theology in this academic degree system in the 1990s and 2000s.

\section{Theology as a "normal" science: the post-soviet experience.}

In the new states that emerged on the political map of Europe after the collapse of the USSR the situation with theology developed differently. On the one hand, in some post-Soviet countries, including Latvia, Lithuania and Estonia, the academic communities recognised theology as a normal scientific discipline and preferred to map it among other humanities. Therefore, the Latvian University, for example, restored in its structure the Faculty of Theology (Teologijas fakultāte), which the communist regime had closed during the Sovietisation in 1940. The Faculty of Theology emerged as a result of a change in the status of the seminary, organized in 1969. Estonian and Latvian universities also began to implement theological educational programs in the 1990s, when churches developed their own universities simultaneously. The Faculty of Theology was re-established at the University of Tartu but unlike the same structure in Latvian University, its name (School of Theology and Religious Studies) is more neutral.

As for the academic degrees in theology, the societies of the Baltic countries perceived their appearance neutrally or positively, realising that it was nothing more than a return to those educational and academic practices that had already existed during the period of independence between the two world wars. Doctoral programs in theology at the Latvian University developed in parallel with the formally secular programs in other humanities.

On the other hand, some post-Soviet countries did not develop the traditions of theological education. In fact, there was no continuity between the pre-Soviet and post-Soviet experiences. Ukraine and Belarus were among such countries, but national education systems were able to integrate theology into educational programs faster than Russia did the same in its education. Belarus became the first post-Soviet country where political elites recog- 
nised theology as an academic speciality, determining it as one of the possible educational trends among humanities. Moreover, the Ministry of Education approved the state educational standard in theology.

The rectorate of Belarus State University in cooperation with the Orthodox Church established the Saints Cyril and Methodius Institute of Theology in 2004. The state and secular status of the university did not become an obstacle to the emergence of a de facto theological faculty in its structure. The specific political culture of Belarus and the peculiarities of the regime excluded public discussions about the intervention of theology into the system of secular higher education. Ministry of Education of Belarus did not include theology as an academic speciality in the degree system in Belarus, although the educational institutions of the Orthodox Church monopolised the right to award the academic degrees of the Candidate and Doctor of Theology. The Belarus case in this situation is dual in its nature: on the one hand, theology was recognised as a speciality in the state system of higher education, whereas, on the other hand, the state does not control the process how the Church awards academic degrees in theology, presuming that the degrees of the Candidate and Doctor of Theology awarded by the Church's educational institutions are sufficient for the Church's needs in the academic attestation.

As for Ukraine, this post-Soviet country experienced a revival of religious education in the 1990s. Educational institutions of Orthodox churches, Catholic and Protestant universities awarded their academic degrees actively. Until the middle of 2000s, a compromise situation persisted in Ukraine, when theology was developed as the part of the "Philosophy" which is a secular specialty. In 2011, the Ministry of Education and Science of Ukraine defined theology as a separate area of "Humanities". The Orthodox Church and other religious educational institutions in Ukraine confer their academic theological degrees, although some of them (for example, the Kiev Orthodox Theological Academy) award the degrees of the Candidate and Doctor of Philosophy with a specialisation in Theology.

Evangelical Theological University (Kyiv) offers an academic program of the Doctor of Practical Theology or the Doctor of Ministry (D.Min.), which in fact became an attempt to transplant the characteristics of academic degrees for Protestant education in the United States. In general, theology was excluded from the system of academic degrees as an independent speciality in some post-Soviet countries, which actualises its frontier status as an interdisciplinary form of knowledge for the supporters of theology and nonscience in the eyes of its critics and opponents simultaneously, forcing potential doctors of theology to obtain academic degrees in the European or American universities. 
Theology as a "church" science: secular and clerical parallel systems of academic degrees. By the moment of the collapse of the Soviet Union, the Church in Russia was separated from the state, which in the postSoviet period did not interfere with the development of religious education. Therefore, practically all religious educational institutions in Russia emerged and developed as non-state, being part of the educational systems of various Churches and religious communities. The educational institutions of the Orthodox Church, as in the Soviet period, awarded its degrees of the Candidate and Doctor of Theology. The Moscow Theological Academy, the Saint Petersburg Theological Academy, Saints Cyril and Methodius Institute for Postgraduate Studies, St. Tikhon Orthodox University for the Humanities, Tsaritsyn Orthodox University of St. Sergius of Radonezh and Novosibirsk St Macarius Orthodox Theological Institute are among the largest Russian educational institutions that offer programs in theology.

The system of degrees of the Candidate and Doctor of Theology in postSoviet Russia reproduced the system that had existed before 1917. Therefore, educational institutions of the Orthodox Church conferred the degrees of the the Candidate (Doctor) of Theology, Candidate (Doctor) of Church History, Candidate (Doctor) of Church Law. However, the secular state recognises these degrees but does not include them formally into the system of academic degrees. Therefore, representatives of the Russian Orthodox Church presume that such situation is unfair (Kosovan, 2017). Educational institutions of the Russian Orthodox Church have the right to organise their Dissertation Councils, which actualise the frontier status of theology in Russia and the gap in academic traditions because council members and opponents in the defence of candidate and doctoral dissertations are often Church hierarchs or scholars who have secular academic degrees, including degrees of the Candidate (or Doctor) of Historical, Philological or Philosophical Sciences.

Expansion or return of theology: the difficulties of overcoming frontiers in secular education. The attempts to start teaching theology, "science in a special sense" (Tyurenkov, 2016), at Russian universities coincided with the first wave of reforms in the post-Soviet higher education. The Ministry of Education of Russia in 1992 recognised "Theology" as a direction of higher education, including it in the classifier of educational specialities. The ministry also approved an educational standard, which, on the one hand, had much in common with the standard for "Religious Studies", but, on the other hand, it made possible to receive state diplomas of "Bachelor of Theology".

The secular state Ministry of Education reintroduced theology in the university curricula but ignored the opinion of the Orthodox Church. In 1992 St. Tikhon's Orthodox Theological Seminary, Omsk State University, 
and Altai State University became the first universities in post-Soviet Russia which began to teach theological disciplines. By the late 1990s, in 1999, the Ministry of Education approved the Master's Standard in Theology. By 2001 eight Russian universities, including Belgorod State University, Sergei Yesenin Ryazan State Pedagogical University, Tula State University, Tula State Pedagogical University, Ural Pedagogical University, and Sarov State Institute of Physics and Technology, had introduced the educational programmes in "Orthodox Theology".

The experience of these Russian universities became an exception to the general logic of the development of the Russian higher education because, on the one hand, it has a secular character, while, on the other hand, the academic community expressed extremely different viewpoints when the Church proposed to integrate theology in the educational system. In this intellectual atmosphere, the opinions of Russian scientists involved in the natural sciences range from the moderately negative to actively hostile. The communities of Russian scientists in the 1990s preferred to ignore the development of theological bachelor's and master's educational programmes rather than the intensification of the educational activities of the Russian Orthodox Church and attempts to obtain permission to award academic degrees in "Theology" at state universities with the actual recognition of theological degrees as equal to the degrees in humanities and natural sciences.

The attempts to integrate theology into the Russian educational system contributed to the discussions and debates about its unscientific nature and pointed out the problems of the frontier of theological knowledge and its boundaries. Ekaterina Elbakyan, Russian sociologist and historian of religion, commenting on the peculiarities of the post-Soviet situation with theology in the field of education, believes that "speaking about Christian theology we remember the division of Christianity into Orthodoxy, Catholicism, Protestantism, Oriental Orthodox churches, each of which is split into many more directions... which of these confessional theologies are we talking about? After all, 'theology in general' does not exist. There are only several specific ideas of certain confessions about God, namely, the doctrine of God, developed in one or another Christian confession. Confessionalism implies a certain ideological choice, a certain unshakable position, limited by the framework of a separate confessional worldview" (Elbakyan, 2015). It became inevitable because the emergence of theology into the educational bachelor and master's programmes and later into the number of academic degrees visualised the problems of the presence or absence in the educational process of those intellectuals who represented confessional theological traditions. Therefore, theology in Russian academic discourse turned out to be 
doomed to stay on the frontier between faith and science, on the one hand, and between various Christian Churches and their theological traditions, on the other hand.

By the middle of 2010s theology had retained its controversial and, as a result, a de facto frontier status stayed on a movable border between various imagined categories which included knowledge and religion, natural and human sciences. On the other hand, by the middle of 2000s intellectuals had assumed the confrontational character of the relationship between theology and its opponents. The attempt to create a collective petition for the recognition of theology as pseudoscience became the culmination of the contradictions between the proponents of theology and their secular opponents. In 2015 secular intellectuals initiated a public campaign to sign a petition recognising theology as pseudoscience. The authors of the petition preferred to use an aggressive discourse that formed and promoted the images of Otherness. Therefore, they argued categorically that theology is not a science, consistently and emphatically insisting that "theology is a pseudoscience, it undermines the authority of science... Theologists with their 'dissertations' dishonour the scientific community, discredit science and philosophy. Taxpayers in a secular state should not contain obscurantists within the walls of state institutions. The place of theology and other faiths is in theological seminaries, separated from the state. In European countries, theology has long been an atavism and a relic of the wild Middle Ages... The philosophy of religion is a critical analysis of religion as a social phenomenon... Religious studies is a science... Religious philosophy is a pseudo-philosophy and a set of myths and dogmas... Religious philosophy is a church project, an attempt to mix religion with philosophy... theology is one of the ecclesiastical concepts, which has no evidence... it is an empty concept from the viewpoint of critical reason. Theology can be defined literally as idle talk... Theology is a set of myths and dogmas imagined by priests as science, but it is not science. Theology is a pseudoscience, a church project, an attempt to mix religion with science" (Mudriy, 2017).

Such ideas, promoted by the radical part of the Russian secular academic community actively, had various consequences. On the one hand, they actualised and visualised the frontier status of theology in the Russian academic community, the uncertainty of its status and the blurred boundaries of the object and subject of theology. On the other hand, the negative perception of theology by representatives of the natural sciences actualised that some of them preferred to reject the perception of science as conventional. The tendency to monopolise the academic discourse, to minimise it and reduce it to the natural sciences also belonged to the number of practices Russian natural scientists used for rejection of theology. This situation actual- 
ised the conflict between two forms of sacredness that coexisted simultaneously in the Russian academic community. The Russian supporters of the natural sciences and apologists of theology preferred to perceive their forms of knowledge sacredly, idealising and mythologizing them. Therefore, the rejection of theology in the Russian academic community became a conflict between two different versions of sacredness, inspired by the fears of supporters of the sacredness of the natural sciences that it would be challenged by theologists, in particular, and other humanitarians in general.

If the recognition of humanitarian degrees was relatively acceptable for Russian physicists, biologists, mathematicians and physicists, then the desire and attempts of the Church to achieve equality between theological and, for example, biological academic degrees faced organized opposition, which had been consolidated by 2017 when Archpriest Pavel Khondzinsky, the Dean of the Theological faculty of the Orthodox St.Tikhon University for the Humanities, defended the first candidate $(\mathrm{PhD})$ thesis in Russia in theology specialisation, which stimulated a new wave of discussions and debates between supporters and opponents of the official status of theology as a scientific discipline.

\section{SOMETIMES THEY RETURN ... OR HOW THEOLOGY TURNED SCIENTISTS INTO COMBATANTS OF "HOLY WARS” AND THE MASS MEDIA BECAME A BATTLEFIELD}

In Russia, where, as some intellectuals believe, "the development of theological education is at the beginning of its way" (Kulikova, 2020) but "theology is confidently entering the educational space" (Tyurenkov, 2018), Pavel Khondzinsky, who defended his dissertations for a $\mathrm{PhD}$ in Theology some years earlier, on June 1, 2017, defended his $\mathrm{PhD}$ dissertation titled "Solving the problems of Russian theology of the 18th century in the synthesis of St.Philaret, Metropolitan of Moscow", and this successful defence allowed him to obtain academic degree confirmed by a state diploma.

Even though Vladimir Filippov, the head of the Higher Attestation Commission in October 2015 recognised the significant historical role of theology in the Western system of university education (Kotlyar, 2015), he was compelled to declare that "in the coming years, there will be no Candidates or Doctors of Theological Sciences in Russia" (Makeyeva, Korobov, Labutina, 2016). The defence of Pavel Khondzinsky could have caused a social and cultural resonance. This defence would have been an ordinary event if it had not been the first defence of a theological dissertation recognised by the state and if Russian biologists had not written and sent six negative reviews.

Despite the attempts of the Church hierarchs to form a positive image of theology and denial of accusations that they use secular universities for 
missionary activity, the anti-theological lobby in the Russian academic community is quite stable and active, and Hilarion's statement that "the departments of theology in secular universities are not the same as the chair of the preacher at the church pulpit" (Hilarion, 2019a) became just another reason for accusations of clericalisation and promotion of unscientific theology. Criticising the position of the Church, secular intellectuals prefer to ignore Hilarion's idea expressed by him in 2011 that "theology is called upon to assimilate critically the knowledge accumulated by secular sciences natural, humanitarian and social" (Hilarion, 2011a; Hilarion, 2011b), integrating their achievements into the discourse of church education.

The activity of Russian scholars and their numerous attempts to prove that theology is not a science, preceded the criticism of the first theological dissertation. Therefore, some Russian intellectuals were active in their attempts to actualise the frontier status of theology, imagining it as a nonscience which is located at the frontier between various humanitarian disciplines. In the first half of the 2000s, Russian intellectuals perceived theology as a frontier field of knowledge, presuming that "the faith of the Church and the experiences of its expression doesn't belong to science in the modern sense of the word and do not claim this status... a scientific speciality for theology is possible and necessary for studies of the faith in its systematic, practical and historical aspects" (Antonov, 2012), but such perception of theology is a recognition of its an interdisciplinary status. As for marginality of theology in comparison with natural sciences, it mutates into frontierness in Russia. This frontier nature forced theology to stay between faith and science, namely, between religion and religious studies. In this situation, some intellectuals propose a compromising approach presuming that theology is an internal form of reflection when religious studies are its external reflection.

Some Russian authors preferred to perceive theology as something nonacademic, localising between ignorance and delusion. Alexey Golubev defined such sentiments as "double-headed positivism" (Golubev, Sergeyev, Drozdova, 2017). This state of theology emerged as the consequence of its marginalisation during the Soviet period, although until 1917 it had a recognised status comparable to its positions in the Western university hierarchy, with the difference that in Russia theology was studied in church educational institutions, having its system of academic degrees and titles. Alexey Muravyov, for example, stated in the early 2010s that "our theological science is in the most deplorable state and it is simply incapable and not ready to turn to face ordinary people... We have no serious researches comparable with the global theological trends" (Muravyov, 2011).

If humanitarian critics of theology appealed to the problems of academic ethics, then biologists, who criticised theology most zealously and actively, 
preferred to construct its pseudoscientific image. The humanitarian and biological criticism of theology in the Russian intellectual situation in the second half of the 2000s had diametrically different theoretical and methodological foundations and backgrounds that actualised its multiple states and forms, the frontier nature in the academic community as well as difficulties in the processes of its institutionalisation and consolidation. Russian Old Believers or moderate religious intellectuals accepted the emergence of theology in the university system sceptically and insisted on the importance of their own historical and cultural experiences. This alternative perception of theology includes the history of non-Orthodox theological traditions presented by Catholic (Lubac, 1999; Lubac, 2013; Lubac, 2003) and Protestant (Tillich, 1951; Tillich, 1957; Tillich, 1963; Niebuhr, 1988) trends in the development in the West. As for the anti-theological lobby, its supporters are unfamiliar with the main results of progress that theology was able to achieve in Europe and America. Constructing and imagining the image of theology as an archaic and traditional form of knowledge, some Russian biologists ignored the history of national schools in the Western Catholic (Gaidamavičius-Gaida, 1974; Maceina, 1970; 1971) and Protestant (Biezais, 1943; Biezais, 1953; Maldonis , 1939; Kundziņš, 1931) theologies, factors of its heterogeneity (Hägglund, 1997; 2003), significant progress (Barth, 1963; Niebuhr, 1932; 1930; 1935) and transformation (Hägglund, 2011; Niebuhr, 1993 ; 1958; 1956) of 20th-century Western theology.

The Russian intellectuals who tend to see theology as another humanities and state that it is normal when theology is represented in universities where intellectuals defend theological dissertations argue with their opponents and emphasise the importance of the external factor. Commenting on the features of gaps and discrepancies in the development of Russian theology, Dmitry Uzlaner states that "theology is developing. We are lagging behind not only in terms of the development of natural sciences but also in theological development and theological perception of the problems of the 21 st century... If we draw a parallel with computer technology, then such theology in the history of theological reflection roughly corresponds to manual counting. It takes a long intellectual and spiritual evolution to go from manual counting to the latest MacBooks" (Uzlaner, 2017c). Recognition of discreteness as lagging and lagging as discreteness visualises frontier changes in Russian theology, which in actual cultural and intellectual contexts exist in some dimensions including the periphery between the science of faith, the border between the humanities and the natural sciences. Theology in this situation continue to occupy the frontier of imagining landscapes between the main international and interdisciplinary trends, on the one hand, 
and tendencies of national provincialisation of theological reflection in academic discourse, on the other hand.

Russian biologists, who, after Pavel Khondzinsky's defence, challenged its fact (Uglanov, 2017), became the main critics of the theological dissertation. Yury Panchin, Doctor of Biological Sciences (Institute for Information Transmission Problems (Kharkevich Institute) of the Russian Academy of Sciences) defined the defence of Pavel Khondzinsky's dissertation as a "legal nonsense" (Panchin, Kravetsky, Korolkov, 2017), stressing that theology, as he believes, "is not a science" (Glikman, 2017). Some Russian intellectuals have categorically claimed that theology is not a science because "the goal of science is to describe the phenomena observed in the world. There is nothing that can be described by theology since there are no phenomena in it that would need it" (Shevtsov, 2020). The dominant majority of critical opinions on theology in the Russian intellectual community arose under the influence of the neoSoviet inertia, collective secular faith in the myth of natural sciences as only sciences and ignorance of facts about what modern theology is. Secular critics of theology prefer to ignore the viewpoints of the Church hierarchs who insisted on the necessity of compromise. For example, Hilarion, Metropolitan of Volokolamsk, emphasises that "theology is also a part of humanities. Theology is the scientific foundation of a religious worldview, which exists in different forms and variants, in different countries, in different languages, in different cultural traditions" (Hilarion, 2017b). Some Russian intellectuals preferred to define such arguments as unscientific, trying to promote a negative image of theology, insisting that "theology is a form of religious scholarship, but certainly not a science in the modern sense of the word... theology and science are intellectual practices, and their results are expressed in the form of texts saturated with specialised terminology and references... the goals of theology and science are practically opposite to each other" (Golubev, Sergeyev, Drozdova, 2017). Denying the scientific status of theology and sending it to church reservations, secular intellectuals themselves actualised the frontier character of theology, stimulating their opponents in their attempts to integrate theology into secular education and providing them with the arguments that theology is a normal science which can be integrated into the system of academic degrees.

For example, Vitaly Levin, Doctor of Technical Sciences, illustrating the unscientific nature of theology, argued that theology will study "how to put a smartphone in the coffin of the deceased - turn on or turn off" (Levin, 2017). If some authors pointed out the importance and necessity of theology, emphasising that "at the end of the 20th century, a theological turn took place in the Western humanitarian... theology brings religion into the social and philosophical space, expands the operational capabilities and 
the sphere of religious thinking... the business of theology is the rational foundation of the theistic worldview, the philosophical reconstruction of religious tradition, the study of routine religiosity" (Shchipkov, 2019), then others prefer to criticise theology, believing that "the position of God is even worse than that of homoeopathy. There are not even bad works that would confirm his existence... no one can formulate how the world in which there is God differs from the world where he does not exist... Until scientific evidence of the existence of God appears, statements about his deeds should also be perceived as unconfirmed statements of mediums, astrologers, fortune tellers and homoeopaths" (Panchin, 2017a).

In this intellectual situation Alexander Panchin characterised by Pavel Khondzinsky as a "believing atheist" (Khondzinsky, 2017) denies a scientific status of theology, even a frontier one, declaring categorically that theology is a religion that imitates science (Panchin, 2017b). Arguing against such arguments, the proponents of theology as a science presume that "the most common arguments against theology are overtly comic in nature" (Uzlaner, 2017c) because their supporters belong to a meaningfully different methodological discourse. If Russian biologists denied the importance and necessity of theology in university education and the Russian system of academic degrees, perceiving it as a pseudoscience, then some Russian religious intellectuals, including Old Believers who stated that the appearance of theology would lead to an exceptional strengthening of the position of the Orthodox Church. Therefore, Alexey Muravyov emphasises that he is not convinced that the restoration of theological positions in university education and the system of academic degrees will lead to an exacerbation of the conflict between faith and science: "Christianity must face the secularisation challenge honestly. As an Orthodox Christian of the Old Believer tradition, I believe that the Old Believer's faith is a history that concerns only me personally. And relations with science are built on a personal basis. The scientific worldview presupposes research that is based on a scientific paradigm, continuity, and the construction of a theory, or rather a hypothesis and verification. Nothing I have mentioned contradicts a personal religious position" (Muravyov, 2017).

While Russian biologists, in their criticism of theology, appealed to the principles of rationality, non-Orthodox religious activists in Russia feared that official recognition of theology will transform it into a part of state policy. The activities of Russian biologists in their struggle against theology on the eve and after the defence of Pavel Khondzinsky were belated. Russian biologists who decided to become responsible for the marginalisation of theology ignored its history including consolidation in the West, where the activity of some theologians, Hans Küng (Küng, 1984; Küng, 1985; Küng, 
1994; Küng, 2000) contributed to its mutation into normal conventional science. Hans Küng inspired the modernisation of Western theology, insisting that it should become truthful, free, critical, non-opportunist, non-conformist, non-authoritarian, and non-traditionalist. In fact, Hans Küng proposed a program for the renewal of theology because other humanities had already gone through their theoretical turns, renewing significantly the paradigms and languages, they used, and, as a result, expanded its methodological foundations and backgrounds.

On the one hand, Russian theologians have organised their own academic association (NOTA), which actualises the frontier character of theology, because only 3 of the 14 members of the Association's council, were hierarchs of the Orthodox Church. On the other hand, in the 2000s and 2010s, theology was able to become one of the topics and directions of the Russian academic periodicals. Several Russian humanitarian journals, including the "Vestnik Tul'skogo Gosudarstvennogo Universiteta. Teologiia" ("Bulletin of the Tula State University. Theology", since 2008), "Aktual'nye problemy pravoslavnoi teologii" ("Actual problems of Orthodox theology", since 2011), "Einai: problemy filosofii i teologii" ("Einai: problems of philosophy and theology", since 2012), "Religiia. Tserkov'. Obshchestvo. Issledovaniia i publikatsii po teologii i religii" ("Religion. Church. Society. Studies and publications on theology and religion", since 2012), "Studia Humanitatis" (since 2013), "Teologiia. Filosofiia. Pravo" ("Theology. Philosophy. Law", since 2016), "Teologiia I obrazovanie" ("Theology and Education", since 2018), "Visual'naia teologiia" ("Visual Theology", since 2019), "Voprosy teologii" ("Issues of Theology", since 2019) have actually become active in promoting theology.

Theological discourse in these journals is extremely heterogeneous, ranging from religious studies and philosophy to theology, and the institutional affiliations of authors are also very diverse, ranging from academic affiliation to church ministry. Academic journals of the Russian Orthodox Church, including "Vestnik Ekaterinburgskoi duhovnoi seminarii" ("Bulletin of the Yekaterinburg Theological Seminary"), "Hristianskoe chtenie" ("Christian Reading"), "Bogoslovskii Vestnik" ("Theological Herald"), "Vestnik Russkoi hristianskoi gumanitarnoi akademii" ("Bulletin of the Russian Christian Humanitarian Academy"), "Vestnik Pravoslavnogo Sviato-Tihonovskogo gumanitarnogo universiteta" ("Bulletin of the Orthodox St. Tikhon Humanitarian University"), also make a significant contribution to the development of theology. Comparing the Church and formally secular academic magazines, it is obvious that they use different languages and modes of description and analysis, forming a heterogeneous and multiple images and dimensions of theology in Russia, which actualise its frontier features in the discourse of modern humanities. 
Commenting on the wars between biologists and theologians, Hilarion, Metropolitan of Volokolamsk, explains their inertia as the expression of "the opposition of religion and science, stemming from the times of forcibly imposed atheism when people were taught that religion is incompatible with science" (Bekshayev, 2018). Russian intellectual, Dmitry Uzlaner, appeals to the authority of academic ethics, believing that the radical statements of biologists, on the one hand, "cast doubt on the adequacy of the speakers", and, on the other hand, "lead to nothing but new rounds of disciplinary wars and a split in the academic community" (Uzlaner, 2017b), which actualises the frontierness and marginality of the humanities in the eyes of their critics and opponents from natural science.

The dominance or significant role of anti-theological statements in the modern Russian intellectual community opens up several dimensions of its functioning, including heterogeneity, ideological fragmentation, and polarisation. These features of the Russian academic communities inspired and made it possible for the frontier status of some forms of humanities to be seen, including those which became victims of marginalisation during the Soviet period. In fact, the cultivation of atheistic forms of scientific imagination and the dominance of the ideas of academic exclusivity only in natural sciences became the incentives that in the 2000s and 2010s inspired Russian scientists to criticise theology in general and the attempts of the church to integrate it into the system of academic degrees, in particular.

The dominance of such sentiments predetermined the controversial status of theology, turning it into a hostage of the informal peculiarities that emerged as a result of its genesis and institutionalisation in post-Soviet Russia. Therefore, theology in Russian science turned into a frontier case because the church became its inspirer. Humanitarian intellectuals make up the majority of scientists involved in theological studies when biologists, chemists, physicists and other representatives of natural sciences seek to monopolise the status of the defenders of correct, "pure" and true science. Those Russian intellectuals who perceived theology as just another science with the theoretical ability to defend dissertations preferred to insist that consistent critics of theology were unaware that modern Western theology is extremely heterogeneous (Uzlaner, 2017a).

Commenting on the reaction of opponents, Pavel Khondzinsky himself stated that they tried "to return us to the days of the communist past... it is a direct and still not obsolete legacy of the Soviet regime. Militant atheism turned the history of the church, its leaders and faith in general into a collection of cartoons" (Lyutykh, 2017). In this situation, it was noteworthy that critics of the theological dissertation were active in using hate speech to form and promote a negative image of their opponents. It is also obvious that 
the arguments of moderate intellectuals were the same in nature, showing the incompleteness of the academic landscape formation in Russia where the dividing lines turned into the frontiers.

The statements of some hierarchs of the Russian Orthodox Church also revealed the frontier nature of theology in the system of university education. For example, Hilarion, Metropolitan of Volokolamsk, mapped and localised theology between philosophy and cultural studies (Hilarion, 2017), trying to integrate it into university education and the system of academic degrees. These moderate ideas of Hilarion led to the intensification of his criticism by secular scholars, who in 2017 proclaimed him an anti-prize laureate for the active promotion of theology into the education system which is defined by some secular authors as the intervention of pseudoscience. Russian intellectuals including representatives of natural sciences and humanities accepted the return of theology differently. Commenting on the active rejection of theology by some representatives of the academic community and their attempts to ridicule it, Anna Shmaina-Velikanova, Doctor of Cultural Studies (RSUH), argued: "the organisers of this award could take a dissertation of any bishop, for example, the dissertation about sermons and declare: 'There is lowimportance scientific content in this dissertation, the culture is low, the bibliography is only in Russian'. Instead, they chose Metropolitan Hilarion. Could any of those who awarded this prise in pseudoscience take Hilarion's doctoral dissertation and discuss ancient Syrian theology with him?" (Shmaina-Velikanova, Borisov, Demina, 2017). Such tactics and strategies of secular scientists, including biologists, restore the frontier status of theology with the difference in other cases of academic frontierness. The opponents of theology themselves turned public acts of denial and rejection into a show, actualising their migration outside the academic community.

Representatives of the humanities, understanding the difficulties of returning theology to universities and the contradictions of its status, sympathised the authors of the first Russian theological dissertations. Commenting on the biological criticism of theology, Alexander Kravetsky, Candidate of Philology (V. V. Vinogradov Russian Language Institute RAS) defined it as "incompetent" (Panchin, Kravetsky, Korolkov, 2017). Alexander Korolkov, Doctor of Philosophy (Institute of Human Philosophy of A. I. Herzen Russian State Pedagogical University) stated that the claims of representatives of the natural sciences are inappropriate and incomprehensible (Panchin, Kravetsky, Korolkov, 2017).

The attempts by Russian intellectuals to justify the defence of a theological dissertation revealed the frontier status of theology in Russia, although some Orthodox priests themselves emphasise the presence of theology between various sciences and forms of knowledge, insisting that the personal 
experience of some theologians "who began to study theology as believers but finished it as convinced atheists" (Barybina, 2020) indicates difficulties of localising theology among other sciences. For example, Pavel Kostylyov (Moscow State University named after M.V. Lomonosov) assumed that "theology is the quintessence of humanitarian knowledge. Thus, the attack of natural scientists on theology is not a new incident, but it is a completely natural continuation of cultivating hostility towards humanitarian knowledge" (Panchin, Kravetsky, Korolkov, 2017), pointed precisely to the unique place, status and position of theology, which is normal for intellectuals engaged in Humanities and something archaic for natural scientists.

Vladimir Filippov, Chairman of the Higher Attestation Commission, tried to find a compromise in this situation supposing that the state and the church can award their degrees, and the state should create conditions for recognition of religious academic degrees and their further equating to secular ones (Panchin, Kravetsky, Korolkov, 2017). The defence of Pavel Khondzinsky's dissertation on theology demonstrated numerous situations of frontierness in the Russian academic community, contradictions between representatives of the humanities and natural sciences, as well as the incompleteness of the process of forming ethical norms and systems of reputation and status in science. Therefore, Anna Danilova (Candidate of Philology, Moscow State University), commenting on the discussions about the first theological dissertation, believed that "it doesn't matter whether you are a believer or not, what method you use and what you are researching if you study Church history, Church Slavonic texts or Patristics - you are deliberately obscurantist... A historian who wrote about the Church does not have the right to become a Education Minister, a philologist, studying the textology of the New Testament is not eligible for an academic degree. This is a very unpleasant trend that refers to real discrimination... such claims are unthinkable in the Western academic system" (Panchin, Kravetsky \& Korolkov, 2017).

The defence of Pavel Khondzinsky became a frontier case in the actual history of the modern Russian academic community because representatives of the Church, secular scientists and government officials from the Ministry of Education were involved into discussion. Olga Vasilyeva, Education Minister in 2017, commenting on the defence, emphasised that theology is only one of the humanities, and, as a result, there is nothing reprehensible in theological dissertations: "we will defend the dissertation in theology, and we will give a degree in Philosophy, History, Philology, Sociology?... what are you talking about? There is Sociology of Religion, but it is a completely different story... We are defending a thesis in theology, and we get a degree in these areas?... it should not be so because from the beginning it was not so" (Vasilyeva, 2017). 


\section{“DO YOU SEE A GOPHER? NO! AND I DON'T SEE IT BUT HERE IT IS!” OR “CALM AFTER THE BATTLE”: THE ILLUSION OF SILENCE AND FORMAL “ABSENCE” OF THEOLOGY IN RUSSIAN MASS MEDIA (2017 - 2020)}

"Do you see a gopher? No! And I don't see it. But here it is!". This phrase from the Russian comedy film "DMB" became a meme on the Russian Internet. The phrase illustrating the presence or absence of something characterises the current state of theology in the discourse of modern Russian mass media. The defence of Pavel Khondzinsky's dissertation and the subsequent award of a degree recognized by the state stimulated discussions and debates, which were the frontier in their nature. The forced and voluntary participants of these debates did not limit themselves in arguments, using both academic, general humanitarian, political and ideological motives to criticise their opponents.

Despite the attempts by the moderate segment of the Russian intellectual community to warn radicals preferring to deny theology in general and criticize its incorporation into the education system and academic degrees, theology did not change its frontier status. If some Russian authors believed that theology could become a positive factor theoretically in the development of education and prevention of religious radicalisation, presuming that "theology is an outpost of reason in religious traditions. If you throw theology out of Catholicism, you will never get the Second Vatican Council. If you throw theology out of Protestantism, then you will get blinkered literalist fanatics blowing up abortion clinics... let's kick theologians out of our society... What do we get? People may think that we will drive out theology, then we will enlighten everyone, religion will disappear, and there will be a society free from religion. Will not be!" (Uzlaner, 2017c), their opponents continued to criticise theology, ignoring moderate viewpoints.

In the period between 2017 and 2020 the Russian academic communities again addressed the problems of theology periodically, emphasising its role and place among sciences and status in the academic community. In 2019 the Russian Orthodox Church, in cooperation with St. Petersburg State University, began publishing the journal "Issues of Theology". Commenting on the tasks of the new journal, Hilarion, Metropolitan of Volokolamsk, pointed out the significant interdisciplinary potential of theology and emphasised that the further development of theology in higher education and the system of academic degrees can influence positively the "interreligious world and sustainable development of the state" (Hilarion, 2019b).

The state, including the Ministry of Education and Science and the Higher Attestation Commission, played the role of a moderator in this conflict between representatives of the Russian academic community, but 
government measures were not so successful, providing incentives for new discussions. On the one hand, several more theological dissertations were defended, and their authors received state academic degrees, but Russian biologists preferred to ignore these defences. On the other hand, "Theology" supplemented the number of academic specialities in Russia. The Ministry of Education and Science approved the academic passport of "Theology", replacing the Passport of 2015, which had much in common with the passport of "Philosophy". The new academic passport did not satisfy secular and religious intellectuals. If the Passport of 2015 allowed defences of theological dissertations with the further award of the Candidate and Doctor academic degrees in History, Philology, Political Science, Art, Pedagogy or Philosophy, then the Passport of 2019 endowed theology with greater independence.

If the Passport of 2015 was had inter-confessional nature, then the Passport of 2019 provided the separation of Orthodox, Islamic and Jewish theologies as academic specialities. The texts of the Passports of 2015 and 2019 had a lot in common because they originated genetically in the depths of the Russian state bureaucracy. Both Passports of academic speciality emphasised the preference to ignore historical Russian and foreign experience. The definitions of the Passport of 2015 are inertial, neo-Soviet and formal in nature because they reduce theology to the analysis of "the system and structure of theology and theological education", "religious apologetics", "theological analysis of sacred texts, doctrinal literature and monuments of religious writing", "theological teachings on the relationship between religious faith and reason" or "theological anthropology".

The text of the Passport of 2019 is more extensive than the text of the Passport of 2015, actualising the need for an academic analysis of "Christian faith, history and methodology of its studies, Orthodox Christianity in the aggregate of its conceptual-theoretical, practical and cultural-historical expressions... the content of Christian doctrine, the practice of religious life, history and socio-cultural aspects of Orthodox Christianity as a traditional confession for Russia”. On the one hand, these definitions stem from the Passport of 2015 genetically, although the division of possible theological degrees in theology, church history and church law seems more appropriate in the contexts of the restoration of its place in the system of academic degrees. On the other hand, modern humanities are interdisciplinary and thematic vectors of dissertation researches are too diverse. Therefore, the Western experience of the system of theological degrees may be partly applicable or relevant and interesting.

Western universities have a historical tradition of awarding several nonsecular academic degrees, including Doctor of Applied Intercultural Studies, Doctor of Clinical Pastoral Counseling, Doctor of Theology, Doctor of Minis- 
terial Leadership, Doctor of Ministry, Doctor of Pastoral Music, Doctor of Practical Theology, Doctor of Sacred Theology, Doctor of Theological Ministry, Doctor of Theology, $\mathrm{PhD}$ in African American Preaching and Sacred Rhetoric, $\mathrm{PhD}$ in Bible, $\mathrm{PhD}$ in Biblical and Ancient Near Eastern Archaeology, $\mathrm{PhD}$ in Biblical Interpretation and Theology, $\mathrm{PhD}$ in Biblical Studies, $\mathrm{PhD}$ in Missiology, $\mathrm{PhD}$ in Renewal Theology, $\mathrm{PhD}$ in Spirituality, $\mathrm{PhD}$ in Theological Studies, $\mathrm{PhD}$ in Theology and Apologetics.

The American academic degree system in theology is extremely heterogeneous and radically different from the Russian system, which is rooted genetically in the Soviet secular academic degree system. If the heterogeneity of American degrees arose as a result of the development of the university system, the institution of reputations and minimal government participation and control, then the modern Russian attempt to recognise theological degrees officially became an expression of the inconsistency and indecision of the state, manoeuvring between the interests of secular academic groups and religious communities.

The lack of opportunities to obtain academic degrees in Protestant and Catholic theology in the new passport for the academic speciality "Theology" actualise the inconsistency of the secular authorities in regulating the status of theological academic degrees. Fears of Catholic and Protestant expansion in this context seem overstated and exaggerated. The hypothetical emergence of the possibility of obtaining academic degrees in Catholic and Protestant theology cannot provoke an explosive growth of dissertation defences. The status and number of the probable Candidates and Doctors of Catholic / Protestant theology would be comparable, for example, to the positions of the Candidates / Doctors of historical sciences in World history, which numerically inferior to the specialists with academic degrees in Russian history.

\section{CONCLUSIONS}

The status of theology in modern Russia continues to remain controversial despite the changes and transformations that have taken place in religious culture, social structure and the system of higher education. Actually, the collapse of the Soviet Union marked the beginning of the processes of religious revival. The tendencies of clericalisation changed the tendencies of secularisation that dominated during the Soviet period. In fact, in post-Soviet Russia, two systems of higher education and, as a result, two different systems of academic degrees coexisted and continue to coexist and function simultaneously.

The secular system of higher education continues to dominate because modern Russia inherited the Soviet organisation of higher education and science, instigating minor changes only while retaining the Soviet systems of 
scientific degrees and the mechanisms of reproduction of the academic community. The collapse of the USSR led to the restoration of the Church role in cultural and social life as well as in education. The Russian Orthodox Church, as well as Catholics and Protestants were allowed to develop their educational systems, including systems of academic degrees of candidate and doctor of theology.

In the 1990s and 2010s these two educational systems coexisted simultaneously and developed as parallel but the growing role and rising political and economic influence of the Church stimulated the activity of hierarchs and religious intellectuals integration in the post-Soviet system of secular higher education. The limited expansion of the Church into secular state universities as well as successful development of church universities convinced religious intellectuals and consistently strengthened them in the idea that the emergence and development of theological departments in the secular system of higher education are not enough without integration theology into the secular system of organising science, including neo-Soviet "passports of specialities of scientists" and mechanisms for the defence of dissertations.

The actual Russian experience of defending theological dissertations with further awarding state academic degrees is not very significant. The number of defended candidate and doctoral theological dissertations in Church universities is incomparably greater than the same defences in the secular universities. Despite this negative tendency, the few precedents of successful defences stimulated internal contradictions in the academic community, inspiring its fragmentation and growth of contradictions between the supporters of secular science and those intellectuals interested in the integration of theology into the secular academic system. The few defences of theological dissertations in the state system emphasised the negative tendencies, including ethical contradictions of the Russian academic community, the unwillingness of its secular segment to accept theology as one of the sciences as well as the consistency and determination of the supporters of integrating theology into the existing hierarchy and structure of sciences.

Possible vectors and trajectories of theology development in the modern Russian academic system are still unclear but the author presumes that the first precedents of theological defences, including defences in secular universities, will stimulate a change in theology's status from the knowledge of the frontier between faith and science into a science comparable to history or philology in criteria of formal representativeness in Russian science.

Unfortunately, several factors complicated this scenario of institutionalisation of theology, including the contradictions between Churches and secular intellectuals, neo-Soviet inertia, secularisation processes as well as 
the collective feelings of prejudice in the natural sciences and the pride of theologians as victims of social and cultural discrimination inspired by contradictions and uncompleted secularisation and the economic fears of secular intellectuals, who perceive the emergence of the candidate and doctoral degrees in theology as a step towards clericalisation of society in the country where church and state are formally separate.

The surge of Russian media interest in theology became one of the last intellectual attempts to change the development vectors of the mass media but this attempt was unsuccessful because the Russian media lost interest in theological issues as they were sold poorly, emphasising other subjects that differed from boring and academic theology which is more commercial and successful. The experience of theology in the Russian media and its misadventures in the intellectual mass media once again proved that society is able to consolidate and turn the media into a battlefield. The author presumes that it cannot be ruled out that other intellectual reasons may become new factors of irritation and activation for the Russian cultural mass media. Russian mass media are ambitious enough to play the role of "masters of the thoughts" of Russian society. This effect will be extremely frightening and its consequences will be insignificant in comparison with the same effect of other media because they prefer to promote and visualise other news, including scandals, wars and high life, which can be sold more successfully than theology.

\section{References}

Antonov, K. (2012, September 13). Theology as an academic specialty. Retrieved from Scholasticist website: http://www.scholast.ru/theology-as-a-science/ (In Russian).

Barth, K. (1963). Evangelical Theology: An Introduction. Grand Rapids, MI: Eerdmans.

Barybina, Y. (2020, September 16). Priest Mikhail Yurov on the dangers of theology. Retrieved from Archangelsk Diocese website: http://www.arh-eparhia.ru/ publications/88923 (In Russian).

Bekshaev, I. (2018). Is Theology a Science or a New "Marxism-Leninism"? Retrieved from Regnum website: https://regnum.ru/news/society/2 371 226.html (In Russian).

Biezais, H. (1943). Kristiānisms laikmetu maiņā [Christianity in changing times]. Rīga: A. Gulbisю. (In Latvian).

Biezais, H. (1953). Kristiānisms, nacionālisms, humanisms [Christianity, nationalism, humanism]. Stokholma: Imanta. (In Latvian).

Bokov, G. (2013). The Specificity of Secular Theology and the Problems of Christian Self-Determination in the Contemporary World. Vestnik of St. Petersburg State University. Series 17, (1), 108-112. (In Russian). 
Elbakian, E. (2015, October 17). Again on theology. Retrieved from Scholast website: http:// www.scholast.ru/more-about-theology/ (In Russian).

Feldmanis, R. (1935). Apvienošanās iespējas mūsdienu protestantismā [Possibilities of Unification in Contemporary Protestantism]. Rīga: Latvijas Universitāte. (In Latvian).

Gaginsky, A. (2019). To be or not to be? The Idea of God in Philosophical Theology. Issues of Theology, (1), 41-55. doi: 10.21638/spbu28.2019.104 (In Russian).

Gaidamavičius-Gaida, P. (1974). Krikščionis tarp kolektyvizmo ir individualizmo [The Christian between collectivism and individualism]. Roma: Lietuvių katalikų mokslo akademija. (In Lithuanian).

Glickman, E. (2017, June 5). God's Pokémon in the Temple of Science. The first defense of a theology dissertation in Russia took place. Including one from biologists and journalists. Retrieved from Novaya Gazeta website: https:/novayagazeta.ru/articles/ 2017/06/03/72 686-bozhi-pokemony-v-hrame-nauki?utm_source=push (In Russian).

Golubev, A., Sergeev, A., \& Drozdova, D. (2017, March 31). 'Theology shapes critical knowledge': Russian scholars argue about theology. Retrieved from Scholast website: http://www.scholast.ru/more-about-theology/ (In Russian).

Hägglund, B. (1997). Trons monster. En handledning i dogmatik [Tron's monster. A Guide to Dogmatics]. Arcus. (In Swedish).

Hägglund, B. (2003). Teologins historia: En dogmhistorisk översikt [The history of theology: An overview of the history of dogma]. Arcus. (In Swedish).

Hägglund, B. (2011). Kunskapsteori och metafysik i teologin - en idéhistorisk tillbakablick [Theory of knowledge and metaphysics in theology-A historical review of ideas]. Arcus (In Swedish).

Hilarion, Metropolitan V. (2011a, October 6). Theology and the Secular Sciences. Retrieved from Scholast website: http://www.scholast.ru/theology-and-secular-sciences/ (In Russian).

Hilarion, Metropolitan V. (2011b, October 6). The Ecclesiastical and the Secular in Humanities Science. Retrieved from Scholast website: http://www.scholast.ru/church-andsecular-in-the-humanities/ (In Russian).

Hilarion, Metropolitan V. (2017a, March 29). Theology is the scientific grounding of the religious worldview. Retrieved from Scholast website: http://www.scholast.ru/alfeevtheology/ (In Russian).

Hilarion, Metropolitan V. (2017b, June 14). Theology in Modern Russia: Formation of the Branch. Retrieved from Patriarchy.ru. Official website of the Moscow Patriarchate. website: http://www.patriarchia.ru/db/text/4 934526.html (In Russian).

Hilarion, Metropolitan V. (2019a). Theology in Modern Russia. Toward the publication of a new journal. Issues in Theology, 1(1), 3-8. doi: 10.21638/spbu28.2019.101 (In Russian).

Hilarion, Metropolitan V. (2019b, May 22). Theology and Theological Education: Perspectives for Development. Retrieved from Patriarchy.ru. Official website of the Moscow Patriarchate. website: http://www.patriarchia.ru/db/text/5 438 957.html (In Russian). 
Hondzinski, P. (2017, September 5). Our overriding idea is to restore the rights of theological science. Retrieved from Tatiana Day. MSU Online Journal. website: https://taday.ru/ text/2 211 884.html (In Russian).

Kosovan, A. (2017, March 3). "There are things that can only be explained by theology". The story of a priest who is defending Russia's first theology dissertation. Retrieved from Snob website: https://snob.ru/selected/entry/121424/ (In Russian).

Kotlyar, P. (2015). Instead of coming from three grandmothers, the priests will go to RGSU". What is the threat of the VAK's introduction of the specialty of "theology". Retrieved from Gazeta.ru website: https://www.gazeta.ru/science/2015/10/13_a_7 816751.shtml (In Russian).

Kulikova, A. (2020, October 25). Religious scholar names difficulties associated with teaching theology at MEPhI. Retrieved from Vzglyad. Delovaya Gazeta. website: https:// vz.ru/news/2020/10/25/1067 196.html (In Russian).

Kundziņš, K. (1931). Kristus: Personība, dzīve un mācība [Christ: Personality, life and teaching]. Rīga: A. Raņķa grāmatu tirgotavas apgādībā. (In Latvian).

Küng, G. (2000). The Great Christian Thinkers. St. Petersburg: Aletheia. (In Russian).

Küng, H. (1984). Paradigmenwechsel in der Theologie: Versuch einer Grundlagenerklärung [Paradigm Shift in Theology: An Attempt at a Basic Explanation]. In H. Küng \& D. Tracy, Theologie - wohin? Auf dem Weg zu einem neuen Paradigma [Theology-Where to? On the way to a new paradigm] (pp. 37-75). Zürich: Guetersloher Verlagshaus. [In German].

Küng, H. (1985). Theologie auf dem Weg zu einem neuen Paradigma [Theology on the way to a new paradigm]. In J. R. Hauer, Entwürfe der Theologie [Drafts of theology] (pp. 181-207). Graz: Styria. (In German).

Küng, H. (1994). Große christliche Denker [Great Christian thinkers]. München: Piper. (In German).

Levin, V. (2017, August 15). Where We're Going. Retrieved from Troitsky variant website: https://trv-science.ru/2017/08/kuda-my-idem/ (In Russian).

Lubac, H. de. (1999). Le drame de l'humanisme athée [The drama of atheistic humanism]. Paris: Cerf. (In French).

Lubac, H. de. (2003). Catholicisme. Les aspects sociaux du dogme [Catholicism. The social aspects of the dogma]. Paris: Cerf. (In French).

Lubac, H. de. (2013). Esprit et liberté dans la tradition théologique. Suivi de Petite catéchèse sur nature et grâce [Spirit and freedom in the theological tradition. Followed by Small catechesis on nature and grace]. Paris: Cerf. (In French).

Lyutykh, S. (2017, July 21). "It is something of a self-reflection of the Church." First Candidate in Theology on why the discipline is worthy of being called a science. Retrieved from Lenta.ru website: https://lenta.ru/articles/2017/07/21/teologia/ (In Russian).

Maceina, A. (1970). Bažnyčia ir pasaulis [The Church and the world]. Čikaga: "Krikščionis gyvenime" knygu serijos. (In Lithuanian). 
Maceina, A. (1971). Didieji dabarties klausimai [The big questions of our time]. Čikaga: "Krikščionis gyvenime" knygų serijos. (In Lithuanian).

Makeeva, A., Korobov, P., \& Labutina, D. (2016, August 11). Theology has been elevated to an academic degree. Theology is officially recognized as a science in Russia. Retrieved from Kommersant website: https:/www.kommersant.ru/doc/3060 218 (In Russian).

Maldonis, V. (1939). Evanǵeliskā dogmātika [Evangelical dogmatics]. Rīgā: Latvijas Universitāte. (In Latvian).

Malimonova, S. (2015). Christian Tradition and Modernism: Approaches to Understanding the Problem. Bulletin of V.N. Tatishchev Volga University, (4), 220-230. (In Russian).

Muravyev, A. (2013, October 10). Theology in medical schools: Why it won't work. Retrieved from Polit.ru website: https://polit.ru/article/2013/10/10/teologiya_med/ (In Russian).

Muravyov, A. (2017, November 21). Theology has no place in higher education, but there is no need to throw stones at it,. Retrieved from Troitsky variant website: https://trvscience.ru/2017/11/aleksei-muravyov-teology/ (In Russian).

Niebuhr, R. (1930). Leaves from the Notebook of a Tamed Cynic. NY: Richard R. Smith.

Niebuhr, R. (1932). Moral Man and Immoral Society: A Study of Ethics and Politics. NY: Charles Scribner's Sons.

Niebuhr, R. (1935). Interpretation of Christian Ethics. NY: Harper and Brothers.

Niebuhr, R. (1956). The Purpose of the Church and Its Ministry. NY: Harper.

Niebuhr, R. (1958). Christ and Culture. NY: Harper Collins.

Niebuhr, R. (1988). The Kingdom of God in America. Middletown: Wesleyan University Press.

Niebuhr, R. (1993). Radical Monotheism and Western Culture: With Supplementary Essays. Louisville: Westminster John Knox Press.

Panchin, A. (2017a, March 8). Five crosses to the grave of theology: Alexander Panchin on why it cannot be considered science. Alexander Panchin's response to theses in defense of theology. Retrieved from The Indicator website: https://indicator.ru/humanitarian-science/tezisy-protiv-teologii-panchin.htm (In Russian).

Panchin, A. (2017b, September 6). Theology is not science, but religion under the guise of science. Retrieved from Tatiana Day. MSU Online Journal. website: https://taday.ru/ text/2212 000.html (In Russian).

Panchin, Y., Kravetsky, A., \& Korolkov, A. (2017, May 26). First Dissertation in Theology: Who and Why Criticizes? And who criticizes the science taught by the best universities in the world. Retrieved from Pravmir website: https://www.pravmir.ru/pochemu-kritika-dissertatsii-po-teologii-1/ (In Russian).

Shchipkov, A. (2019, April 10). The Future of Theology: Why Russia Needs to Develop its School. How Russians can avoid becoming submissive consumers of other people's ideas. Retrieved from Nezavisimaya Gazeta website: https:/www.ng.ru/kartblansh/ 2019-04-10/3_7553_kartblansh.html (In Russian). 
Shevtsov, N. (2020, September 4). Why theology is not science. Retrieved from Popular Mechanics website: https://www.popmech.ru/editorial/616363-pochemu-teologiyane-nauka/ (In Russian).

Shmaina-Velikanova, A., Borisov, M., \& Demina, N. (2017, December 19). "Theology can be taught but should not be implemented." Retrieved from Troitsky variant. website: https://trv-science.ru/2017/12/teologiyu-mozhno-prepodavat-no-ne-sleduetvnedryat/ (In Russian).

Shmonin, D. (2019). Scientific rationality and the "return to theology". Issues in Theology, (3), 280-306. doi: 10.21638/spbu28.2019.301 (In Russian).

Snisarenko, Y. (2020). Theology in the International Scientific and Educational Space. Issues in Theology, 2(1), 118-136. doi: 10.21638/spbu28.2020.108 (In Russian).

Tillich, P. (1951). Systematic Theology (Vol. 1). Chicago: University of Chicago Press.

Tillich, P. (1957). Systematic Theology (Vol. 2). Chicago: University of Chicago Press.

Tillich, P. (1963). Systematic Theology (Vol. 3). Chicago: University of Chicago Press.

Tyurenkov, M. (2016, February 8). Theology: Intruder or ancestor of the sciences? Retrieved from Tsargrad website: https://tsargrad.tv/articles/teologija-nezvanaja-gostja-ili-rodonachalnica-nauk_4359 (In Russian).

Tyurenkov, M. (2018, November 2). Archpriest Dimitriy Leskin: "Theology is steadily entering the educational space of Russia." Retrieved from Tsargrad website: https://tsargrad.tv/articles/protoierej-dimitrij-leskin-teologija-uverenno-vhodit-v-obrazovatelnoe-prostranstvo-rossii_167 077 (In Russian).

Uglanov, F. (2017, July 30). Protopriest's degree revoked. Scholars appeal the awarding of the first degree in theology. Retrieved from Gazeta.ru website: https:/www.gazeta.ru/ science/2017/07/30_a_10811336.shtml (In Russian).

Uzlaner, D. (2017a, March 7). Ten theses in defense of theology as a scientific discipline. On the God hypothesis, pseudoscience, and the rational approach to religion. Retrieved from The Indicator. website: https://indicator.ru/humanitarian-science/teologiyakak-nauka.htm (In Russian).

Uzlaner, D. (2017b, March 9). A call for complexity in an age of simplicity: New arguments for theology. Retrieved from The Indicator. website: https://indicator.ru/humanitarian-science/teologiya-bog-religiya-gumanitarnye.htm (In Russian).

Uzlaner, D. (2017c, March 16). Academic theology can be confessional, extra-confessional, non-religious, and even atheistic. Retrieved from Scholast website: http:// www.scholast.ru/akademicheskaja-teologija-mozhet-byt-vnekonfessionalnoj/ (In Russian).

Vasilyeva, O. (2019, August 8). The first scientist-theologian in the Russian Federation received a $\mathrm{PhD}$ degree. The head of the Russian Ministry of Education and Science, Vasilyeva, read the thesis of the archpriest and considered it good. Retrieved from Interfax website: https://www.interfax.ru/russia/573 909 (In Russian).

Wise, R. (2017). Recognize theology as pseudoscience. Retrieved from. Change.org website: https://www.change.org/p/ (In Russian). 


\section{Список литературы}

Barth, K. (1963). Evangelical Theology: An Introduction. Grand Rapids, MI: Eerdmans.

Biezais, H. (1943). Kristiānisms laikmetu maiṇā [Christianity in changing times]. Rīga: A. Gulbisю. (In Latvian).

Biezais, H. (1953). Kristiānisms, nacionālisms, humanisms [Christianity, nationalism, humanism]. Stokholma: Imanta. (In Latvian).

Feldmanis, R. (1935). Apvienošanās iespējas mūsdienu protestantismā [Possibilities of Unification in Contemporary Protestantism]. Rīga: Latvijas Universitāte. (In Latvian).

Gaidamavičius-Gaida, P. (1974). Krikščionis tarp kolektyvizmo ir individualizmo [The Christian between collectivism and individualism]. Roma: Lietuvių katalikų mokslo akademija. (In Lithuanian).

Hägglund, B. (1997). Trons monster. En handledning i dogmatik [Tron's monster. A Guide to Dogmatics]. Arcus. (In Swedish).

Hägglund, B. (2003). Teologins historia: En dogmhistorisk översikt [The history of theology: An overview of the history of dogma]. Arcus. (In Swedish).

Hägglund, B. (2011). Kunskapsteori och metafysik i teologin - en idéhistorisk tillbakablick [Theory of knowledge and metaphysics in theology-A historical review of ideas]. Arcus (In Swedish).

Kundziņš, K. (1931). Kristus: Personība, dzìve un mācība [Christ: Personality, life and teaching]. Rīga: A. Raņķ̧a grāmatu tirgotavas apgādībā. (In Latvian).

Küng, H. (1984). Paradigmenwechsel in der Theologie: Versuch einer Grundlagenerklärung [Paradigm Shift in Theology: An Attempt at a Basic Explanation]. In H. Küng \& D. Tracy, Theologie - wohin? Auf dem Weg zu einem neuen Paradigma [Theology-Where to? On the way to a new paradigm] (pp. 37-75). Zürich: Guetersloher Verlagshaus. [In German].

Küng, H. (1985). Theologie auf dem Weg zu einem neuen Paradigma [Theology on the way to a new paradigm]. In J. R. Hauer, Entwürfe der Theologie [Drafts of theology] (pp. 181-207). Graz: Styria. (In German).

Küng, H. (1994). Große christliche Denker [Great Christian thinkers]. München: Piper. (In German).

Lubac, H. de. (1999). Le drame de l'humanisme athée [The drama of atheistic humanism]. Paris: Cerf. (In French).

Lubac, H. de. (2003). Catholicisme. Les aspects sociaux du dogme [Catholicism. The social aspects of the dogma]. Paris: Cerf. (In French).

Lubac, H. de. (2013). Esprit et liberté dans la tradition théologique. Suivi de Petite catéchèse sur nature et grâce [Spirit and freedom in the theological tradition. Followed by Small catechesis on nature and grace]. Paris: Cerf. (In French).

Maceina, A. (1970). Bažnyčia ir pasaulis [The Church and the world]. Čikaga: "Krikščionis gyvenime" knygu serijos. (In Lithuanian). 
Maceina, A. (1971). Didieji dabarties klausimai [The big questions of our time]. Čikaga: "Krikščionis gyvenime" knygų serijos. (In Lithuanian).

Maldonis, V. (1939). Evanǵeliskā dogmātika [Evangelical dogmatics]. Rīgā: Latvijas Universitāte. (In Latvian).

Niebuhr, R. (1930). Leaves from the Notebook of a Tamed Cynic. NY: Richard R. Smith.

Niebuhr, R. (1932). Moral Man and Immoral Society: A Study of Ethics and Politics. NY: Charles Scribner's Sons.

Niebuhr, R. (1935). Interpretation of Christian Ethics. NY: Harper and Brothers.

Niebuhr, R. (1956). The Purpose of the Church and Its Ministry. NY: Harper.

Niebuhr, R. (1958). Christ and Culture. NY: Harper Collins.

Niebuhr, R. (1988). The Kingdom of God in America. Middletown: Wesleyan University Press.

Niebuhr, R. (1993). Radical Monotheism and Western Culture: With Supplementary Essays. Louisville: Westminster John Knox Press.

Tillich, P. (1951). Systematic Theology (Vol. 1). Chicago: University of Chicago Press.

Tillich, P. (1957). Systematic Theology (Vol. 2). Chicago: University of Chicago Press.

Tillich, P. (1963). Systematic Theology (Vol. 3). Chicago: University of Chicago Press.

Антонов, К. (2012, сентябрь 13). Теология как научная специальность. Извлечено от Схоласт website: http://www.scholast.ru/theology-as-a-science/

Барыбина, Ю. (2020, сентябрь 16). Священник Михаил Юров об опасности теологии. Извлечено от Архангельская епархия website: http://www.arh-eparhia.ru/ publications/88 923

Бекшаев, И. (2018). Теология - наука или новый «марксизм-ленинизм»? Извлечено от Регнум website: https://regnum.ru/news/society/2371 226.html

Боков, Г. (2013). Специфика секулярной теологии и проблемы христианского самоопределения в современном мире. Вестник СПбГУ. Серия 17, (1), 108-112.

Васильева, О. (2019, август 8). Первый ученый-теолог в РФ получил диплом кандидата наук. Глава Минобрнауки РФ Васильева читала диссертацию протоиерея и сочла ее хорошей. Извлечено от Интерфакс website: https://www.interfax.ru/ russia/573909

Гагинский, А. (2019). Быть или не быть? Идея Бога в философской теологии. Bonpocы теологии, (1), 41-55. doi: 10.21638/spbu28.2019.104

Гликман, Е. (2017, июнь 5). Божьи покемоны в храме науки. В России состоялась первая защита диссертации по теологии. В том числе - от биологов и журналистов. Извлечено от Новая газета website: https://novayagazeta.ru/articles/ 2017/06/03/72 686-bozhi-pokemony-v-hrame-nauki?utm_source=push

Голубев, А., Сергеев, А., \& Дроздова, Д. (2017, март 31). Теология формирует критическое знание»: Российские ученые спорят о теологии. Извлечено от Схоласт website: http://www.scholast.ru/more-about-theology/ 
Иларион, митрополит В. (2011а, октябрь 6). Богословие и светские науки. Извлечено от Схоласт website: http://www.scholast.ru/theology-and-secular-sciences/

Иларион, митрополит В. (2011b, октябрь 6). Церковное и светское в гуманитарной науке. Извлечено от Схоласт website: http://www.scholast.ru/church-and-secularin-the-humanities/

Иларион, митрополит В. (2017а, март 29). Теология - это научное обоснование религиозного мировоззрения. Извлечено от Схоласт website: http:// www.scholast.ru/alfeev-theology/

Иларион, митрополит В. (2017b, июнь 14). Теология в современной России: Становление отрасли. Извлечено от Патриархия.ru. Официальный сайт Московского Патриархата website: http://www.patriarchia.ru/db/text/4 934526.html

Иларион, митрополит В. (2019а). Теология в современной России. К изданию нового журнала. Вопросы теологии, 1(1), 3-8. doi: 10.21638/spbu28.2019.101

Иларион, митрополит В. (2019b, май 22). Теология и теологическое образование: Перспективы развития. Извлечено от Патриархия.ru. Официальный сайт Московского Патриархата website: http://www.patriarchia.ru/db/text/5 438 957.html

Косован, А. (2017, март 3). «Есть вещи, объяснимые только теологией». История священника, который защищает первую в России диссертацию по богословию. Извлечено от Сноб website: https://snob.ru/selected/entry/121424/

Котляр, П. (2015). Вместо прихода из трех бабок попы пойдут в РГГУ». Чем грозит введение ВАК специальности «теология». Извлечено от Газета.ру website: https://www.gazeta.ru/science/2015/10/13_a_7816751.shtml

Куликова, А. (2020, октябрь 25). Религиовед назвал связанные с преподаванием теологии в МИФИ сложности. Извлечено от Взгляд. Деловая газета website: https://vz.ru/news/2020/10/25/1067 196.html

Кюнг, Г. (2000). Великие христианские мыслители. Санкт-Петербург: Алетейя.

Левин, В. (2017, август 15). Куда мы идем. Извлечено от Троицкий вариант website: https://trv-science.ru/2017/08/kuda-my-idem/

Лютых, С. (2017, июль 21). «Это что-то вроде саморефлексии Церкви». Первый кандидат теологии о том, почему эта дисциплина достойна называться наукой. Извлечено от Лента.py website: https:/lenta.ru/articles/2017/07/21/teologia/

Макеева, А., Коробов, П., \& Лабутина, Д. (2016, август 11). Богословие возвели в ученую степень. Теология в России официально признана наукой. Извлечено от Коммерсант website: https://www.kommersant.ru/doc/3060218

Малимонова, С. (2015). Христианская традиция и модернизм: Подходы к пониманию проблемы. Вестник Волжского университета им. В.Н. Татищева, (4), 220230.

Мудрый, Р. (2017). Признать теологию лженаукой. Извлечено от Change.org website: https://www.change.org/p/

Муравьев, А. (2013, октябрь 10). Теология в медвузах: Почему не получится. Извлечено от Полит.py website: https://polit.ru/article/2013/10/10/teologiya_med/ 
Муравьёв, А. (2017, ноябрь 21). Теологии нет места в вузах, но в нее не нужно кидать камни,. Извлечено от Троицкий вариант website: https:/trv-science.ru/ 2017/11/aleksei-muravyov-teology/

Панчин, А. (2017а, март 8). Пять крестов на могилу теологии: Александр Панчин о том, почему она не может считаться наукой. Ответ Александра Панчина на тезисы в защиту теологии. Извлечено от Индикатор website: https:// indicator.ru/humanitarian-science/tezisy-protiv-teologii-panchin.htm

Панчин, А. (2017b, сентябрь 6). Теология - не наука, а религия под видом науки. Извлечено от Татьянин день. Интернет-журнал МГУ website: https://taday.ru/ text/2 $212000 . h t m l$

Панчин, Ю., Кравецкий, А., \& Корольков, А. (2017, май 26). Первая диссертация по теологии: Кто и почему критикует? И кто критикует науку, которой учат лучшие университеты мира. Извлечено от Правмир website: https:// www.pravmir.ru/pochemu-kritika-dissertatsii-po-teologii-1/

Снисаренко, Ю. (2020). Теология в международном научно-образовательном пространстве. Вопросы теологии, 2(1), 118-136. doi: 10.21638/spbu28.2020.108

Тюренков, М. (2016, февраль 8). Теология: Незваная гостья или родоначальница наук? Извлечено от Царьград website: https://tsargrad.tv/articles/teologijanezvanaja-gostja-ili-rodonachalnica-nauk_4359

Тюренков, М. (2018, ноябрь 2). Протоиерей Димитрий Лескин: «Теология уверенно входит в образовательное пространство России». Извлечено от Царьград website: https://tsargrad.tv/articles/protoierej-dimitrij-leskin-teologija-uverennovhodit-v-obrazovatelnoe-prostranstvo-rossii_167077

Угланов, Ф. (2017, июль 30). Протоиерея степени лишают. Ученые обжаловали присуждение первой ученой степени по теологии. Извлечено от Газета.py website: https:/www.gazeta.ru/science/2017/07/30_a_10811336.shtml

Узланер, Д. (2017а, март 7). Десять тезисов в защиту теологии как научной дисциплины. О гипотезе Бога, лженаучности и рациональном подходе к религии. Извлечено от Индикатор website: https://indicator.ru/humanitarian-science/ teologiya-kak-nauka.htm

Узланер, Д. (2017b, март 9). Призыв к сложности в век простоты: Новые доводы в защиту теологии. Извлечено от Индикатор website: https:/indicator.ru/ humanitarian-science/teologiya-bog-religiya-gumanitarnye.htm

Узланер, Д. (2017с, март 16). Академическая теология может быть конфессиональной, внеконфессиональной, внерелигиозной и даже атеистической. Извлечено от Схоласт website: http://www.scholast.ru/akademicheskaja-teologija-mozhet-bytvnekonfessionalnoj/

Хондзинский, П. (2017, сентябрь 5). Наша сверхидея - восстановление прав богословской науки. Извлечено от Татьянин день. Интернет-журнал МГУ website: https://taday.ru/text/2 211884.html

Шевцов, Н. (2020, сентябрь 4). Почему теология - не наука. Извлечено от Популярная механика website: https:/www.popmech.ru/editorial/616363-pochemu-teologiyane-nauka/ 
Шмаина-Великанова, А., Борисов, М., \& Демина, Н. (2017, декабрь 19). «Теологию можно преподавать, но не следует внедрять». Извлечено от Троицкий вариaнт website: https://trv-science.ru/2017/12/teologiyu-mozhno-prepodavat-no-nesleduet-vnedryat/

Шмонин, Д. (2019). Научная рациональность и «возвращение к теологии». Bonpocы теологии, (3), 280-306. doi: 10.21638/spbu28.2019.301

Щипков, А. (2019, апрель 10). Будущее теологии: Почему России надо развивать свою школу. Как русским не стать покорными потребителями чужих идей. Извлечено от Независимая газета website: https://www.ng.ru/kartblansh/201904-10/3_7553_kartblansh.html

Элбакян, Е. (2015, октябрь 17). И снова о теологии. Извлечено от Схоласт website: http://www.scholast.ru/more-about-theology/ 